\title{
THE EVALUATION OF THE EQUIPMENT AND QUALITY OF THE PUBLIC SPACE OF POZNAŃ
}

\author{
Waldemar W. Budner, assoc. prof., PhD \\ Faculty of Management \\ Poznañ University of Economics \\ e-mail:w.budner@ue.poznan.pl
}

\begin{abstract}
The article defines the notion of public space and attempts to explain its forms and roles. The article realizes two cognitive goals: the evaluation of the equipment of public spaces in Poznan with the selected elements of landscape architecture and the quality of those spaces. Empirical research was conducted in the form of a survey addressed at 300 respondents. The research activities conducted in the course of work allow for the formulation of the following conclusions: the quality of life in a city depends on the condition of equipment of public space; the elements of landscape architecture make the public space of Poznan more attractive (contribute to its functionality, increase the aesthetics of urban space); the condition of the equipment of public space with landscape architecture is evaluated as good; the users of the public space in Poznan pointed out the problem of advertising pillars, advertisements and signboards, public toilets and the insufficient number of seats.
\end{abstract}

Key words: public space, equipment, quality, form, role.

JEL Classification: R52, R53.

Citation: Budner W. W., 2016, The Evaluation of the Equipment and Quality of the Public Space of Poznan, Real Estate Management and Valuation, vol. 24, no. 2, pp. 25-33.

DOI: 10.1515/remav-2016-0011

\section{Introduction}

Public space is an immanent element of every city, unfortunately, not infrequently very neglected. Public space of Polish cities is undergoing a crisis, despite the fact that changes have been taking place in those areas for quite some time now. However, the inhabitants evaluate those changes rather negatively, irrespective of how they actually understand this space. Unfortunately, the very concept, form and role of public space, despite its ubiquity, are often difficult to specify.

The article attempts to explain these concepts, and primarily, fulfils two cognitive objectives: 1) evaluation of the equipment of public spaces in Poznan with the items of landscape architecture (artistic - sculptures and monuments; fountains and water springs; information signs - boards, signposts, pictograms, maps; lighting - lamps and lanterns; litter bins; benches; advertising posters; advertising pillars and information boards); 2) evaluation of the quality of those spaces.

The research ${ }^{1}$ involved a survey addressed at 300 respondents, who are the users of public spaces of Poznań. The sample consisted of 160 women and 140 men (a share of 53\% and 47\% respectively). The subject touched upon in the questionnaire is relatively difficult and requires a certain level of general knowledge acquired through experience, therefore the respondents were selected from among adults. $2 / 3$ of them are inhabitants of Poznan $(55 \%)$ and the Poznan agglomeration $(10 \%)$. The opinions of this group of respondents provided the information on how the citizens of this city perceive the public spaces they experience on the daily basis. The remaining participants $(1 / 3)$ are the

\footnotetext{
1 The survey was conducted by Aleksandra Mazur in the middle of 2013.
} 
inhabitants of other towns in the territory of Greater Poland. Their observations are also very significant, as it is possible to verify how public space is perceived by its immediate users, who usually have no emotional ties with those places, and do not identify themselves with them. The main group of respondents (80\%) consisted of young and middle-aged people (18-43). The elderly had a less numerous representation: $13 \%-44-59$ years old $7 \%$ - 60 years old and more. The respondents are well-educated. Most participants have a degree of higher education $(66 \%)$ or secondary education (31\%). People with vocational education constituted a mere 3\% share. When analysing the composition of respondents by professional status, the domination of two groups can be noticed, i.e.: professionals (42\%) and students (46\%). Pensioners, entrepreneurs and unemployed people constituted a mere $12 \%$ of the population surveyed. In this way a profile of a respondent was obtained, being a young (or middle-aged) dweller of Poznań, professionally active, holding a degree of higher education (or still in the course of studies). The above-presented sample is not fully representative, however, it enables drawing limited conclusions which leading to generalizations.

\section{The notion and the role of public space}

Public space is one of the basic components of the spatial structure of each city. Its quality plays a vital role in the life of inhabitants and the development of the city. Public space of every city concentrates the city's public life and becomes its landmark (image) and the symbol of the city's identity, becomes a destination for tourists and other visitors, is a place of work and entertainment, a meeting ground for its dwellers as well as cultural and sports events area.

The concept of public space is defined in the literature in a number of different ways: as a space being the property of everyone - non-private, public available, serving the general public, designed for everyone, or a space creating various social interactions. Another interpretation of public space is included in Karta Przestrzeni Publicznej (THE Public SPACE CHARTER 2009). This document assumes that the character of public space is determined by the way in which it is utilised, rather than its ownership. Besides, the document emphasizes that space is public in character, because it is jointly used by different entities. As construed by the Charter, public space is 'the common property used jointly, purposefully shaped by people in accordance with the social principles and values - serving to satisfy the needs of local and supralocal communities'. The concept of common property should always be superindividual and supra-unitary and have a collective dimension. Whereas the concept of 'public' refers to human collective in the context of common interests, serving the general public and being designed and available to everyone. Hence, as public property one should understand only such property which for natural reasons can serve the local community or the entire society and is consumed in equal proportion by all members of a given community (HEFFNER, MARSZAŁ 2012, p. 11). Public space has a strategic importance for local communities, because it caters for their various needs. Special value is attributed to it also because it bears witness to a city's identity, and is a guarantor of its sustainable development as well (THE PUBLIC SPACE CHARTER 2009).

According to KOWALCZYK (2009) the concept of public space is frequently connected with the availability of space; a similar approach was presented by WEJCHERT (1974), who defined public space as a space which is available to the entire public, including the visitors, which facilitates the intensification of urban life. This space comprises mostly: squares, streets, roads, generally available buildings being public property, as well as parks, greeneries, boulevards. Additionally, socially, service-wise and culturally significant facilities are located in close vicinity to such spaces. Both authors point out the general availability of these spaces for all individuals, as well as its unconditionality - public space is a common space, facilitating the formation of social relations, which in turn satisfy various social needs. DYMNICKA (2009, p. 19) emphasizes, that in a space available to everyone, each citizen has the right to freely express opinions, make acquaintances, build contacts and diverse relations, as well as express behaviours.

In a similar fashion the Spatial planning and development act (2003, article 2, item 6) defines public space as an 'area of particular importance in meeting the needs of inhabitants, improving quality of their life and enabling the establishment of social contacts due to its location, as well as functional and spatial characteristics, specified in the study of conditions and directions of spatial management of the municipality'.

The task of every public space is to create favourable conditions for building interpersonal relations and social development. Participation in the life of a local community and experience stemming from it exert influence on people's social development. Moreover, the stimulation of social 
activity can be affected by the appropriate quality and quantity of spaces fulfilling the role of meeting venues. Such attributes of space as: the benefits of location, accessibility, as well as the attractiveness of architectural forms, are of great importance. Public spaces fulfil the tasks of great significance for the development of social entities, as well as for the development of various communities, which perceive the access to public places and generally available spaces as a prerequisite to their existence. The standard of urban public spaces can reflect the extent to which basic social needs are satisfied. The presence of facilities and spaces of public character in a town is, in a way relevant to the degree to which social needs are met (MAGA - JAGIELNICKA 2012, p. 34).

In conclusion, public space is an example of a public property of local character. Its value in use is addressed at the general public, and access to it should be granted to everyone, and everyone may use it. The particular importance of this area is in satisfying the needs of local communities, which stems first of all from its location, and also from its functional and spatial characteristics (CZEPCZYŃSKI 2012, p. 12). For this reason public space is very important, as it affects the quality of life of its users (i.e. not only the inhabitants), being one of the most significant measuring factors of urban development. In this way it creates the so-called megaproduct (MARKOWSKI 1999), whose social manifestation is in the image and the identity of a city.

\section{Forms of public space}

Within the structures of every city there are places and facilities of importance to everyone, and serving everyone, exceptional - creating the public space. It can take on many different forms. SIERECKA - NOWAKOWSKA (2001, p. 45) distinguishes among them whole areas, structures and buildings, streets, as well as the elements of natural environment.

Due to the shape, and size of the area they occupy, LITWIŃSKA (2012, p. 23-24) lists three forms of public space: facility (a building or a set of buildings), lane space (e.g. street, avenue, shore), surface space (e.g. square, marketplace, park, body of water). A similar breakdown of public spaces was provided by KOCHANOWSKA (2010, p. 21-22), where two groups of spaces were listed. These are:

1) A traditionally shaped street (communication trail), lined with buildings (mainly of commercial and service-providing purposes - the combination of commercial and service-provider functions strengthens the intensity of contacts and behaviours of users of the space),

2) An urban square - large space which attracts users for longer mostly through tradition. Its functioning is enriched by diversified forms of greenery, items of landscape architecture, other attractions (e.g. public utility facilities).

Besides, the author indicates a sizeable group of other more specific forms of organization of those spaces, which are mutations of the universal types (e.g. boulevard, city square, etc.), as well as a number of spaces treated as public, despite the fact that their pronounced functional specialization gives them a specific character. These include the public greenery areas, sports facilities, etc.

According to GRACZYK and STASZEWSKA (2012, p. 136-138), squares, marketplaces or pedestrian streets are specific examples of public space and have always been important components of the urban structure of cities. They have fulfilled the most important functions and accommodated versatile urban forms. Next to streets the most important public spaces in cities are marketplaces and squares. They are 'places in which the speed of life and spatial changes are manifested in the most pronounced way'. They are the spaces in which day-to-day and festive scenes of life of the inhabitants and visitors take place.

The forms of public space may affect the emotional attitude people have towards the place they live in. The neighbourhood is of key importance, it is an element of public space. Being attached to the neighbourhood involves the sense of security and the willingness to integrate with the local inhabitants. Based on this approach ZBIERSKA (2010, p. 360) distinguishes two forms of space2: green space, service space.

The former are first of all places of recreation and free-time activities, among others green areas around bodies of water, squares, parks. They include areas located more or less within a three-minute walk from the place of residence. Such a distance allows an efficient use of the space. It also creates an opportunity for interactions between neighbours, not necessarily of verbal nature. Within a greenery there should be benches, stairs, chairs, and similar items of landscape architecture, where one can sit

2 See CH. AlEXANDER et al. (2008) for further details on the subject. 
outdoors; the greatest concentration of population can be seen in the vicinity of such areas. These places must be designed for users of any age, for the elderly who like watching the surroundings, playgrounds for children. It is best when such spaces are connected with one another through a network of walkways leading from residential buildings. The presence of trees along alleyways is important to protect the walkers against sunlight. The area must be excluded from car traffic (ZBIERSKA 2010, p. 360-361).

Service areas are places where shops and other commercial and service facilities are present, e.g. restaurants. Access by cars must be banned. Service outlets should be arranged around a square which is an ideal venue for gatherings of inhabitants while shopping. The same function can be provided by a local marketplace, where many sellers are congregated under a single roofing (ZBIERSKA 2010, p. 361).

LORENS (2010) points out that the types and functions of public spaces change over time. Their formation under the influence of time can be observed. Other factors determining the changes of traditional public space are: the suppression of petty commerce by large commercial facilities, the deterioration of an industrial city and consequently the urban lifestyle within city centre and its replacement by a modern city. Also the broadly understood globalization.

\section{The equipment and the quality of public space}

The equipment of public spaces should facilitate comfort and safety and also exert a positive influence on the development of social relations. One of the major tasks of public space is to create favourable conditions to cater for the physiological needs of people. Such a space should be well-groomed, clean, safe, and should create a positive climate for health. Dangerous spaces should be eliminated, while those which broaden the recreational offer of a city should be taken care of.

Safety means stability, guarantees harmony and creates conditions for the development of individuals. It is one of the most basic human needs that ensures physical and psychical comfort. It guarantees the lack of fear for the loss of values such as life, health, feelings, respect, work or goods, both material and non-material (FILIPCZUK 1988, p. 105). The equipment and condition of public spaces should improve the well-being of their users. The reason for problems with public space is frequently communication, so efforts should be made to eliminate potential hazards by removing barriers for disabled people, building pavements for pedestrians and bicycle lanes (segregation of traffic), as well as by removing collisions. Also the proportions and size of spatial forms, colours, lighting and the abundance of decorative items affect the sense of security.

A space which is easily accessible and visible can be viewed as desirable. The ease of moving around it enables the use of its different parts. The better the space is equipped and the more comfortable it is, the more willingly people use it. Accessibility is also facilitated by the appropriate development and the ease of perception of the information signs. The accessibility of such places is affected by the rotation of parking space usage and a short distance from public transport.

The sense of security, neatness, cleanliness, as well as the broadly understood attractiveness frequently condition the choice of space we want to spend time in. The attractiveness of a given place is determined among others by the presence of well-groomed greenery, playgrounds, parks or equipment with the elements of landscape architecture, e.g. benches, and first and foremost by the atmosphere and character of the space.

MAGA - JAGIELNICKA (2012, p. 36) claims that the methods of public space development are the evidence of the level of satisfaction of people's needs, especially the social ones. Whereas the extent to which the needs are satisfied can be a reflection of the public space quality. Public spaces can play an educational role, and appropriate spatial conditions exert a substantial effect on increasing the level of needs satisfaction. It is very important to introduce art into the space and to enrich it with greenery.

The quality of public space can be improved by its renovation, comprehensive and cohesive design of new space development with the use of high quality elements of landscape architecture. According to MARKOWSKI (2001, p. 18) the quality of public spaces is greatly affected by institutions of different kinds and citizens of high income (the so-called art sponsors). Unfortunately, significant investors often threaten the historic features of those areas. The negotiating competences and skills of city authorities are usually insufficient to help counteract such phenomena. The problem is also in the inept financing scheme of city development, and more specifically its absence. The city authorities have limited possibilities to conduct a proactive policy of development. The quality of a city's communication system also determines the quality of public space - it is important from the 
inhabitants' point of view because it is one of the elements of their environment and it also determines business activity (MARKOWSKI, 2001, p. 21).

To sum up, we can claim that functional, aesthetic and trim space has a positive effect on the wellbeing of its users. Interesting arrangement of public space encourages to stay in it and to experience it. It also has a substantial effect on the identification of inhabitants with the place they live in. It can provoke all kinds of positive interactions between people: minimise distance and hostility, stimulate intellectually, encourage playing together, social meetings, walks, relaxation.

\section{The evaluation of the equipment of the public space of Poznan}

It is very important to consider the functionality and the degree of saturation with public spaces in the process of shaping them. The elements of landscape architecture such as: benches, monuments and sculptures, fountains, litter bins and other architectural details have a significant effect on the quality of life in a city. The comfort of participants of urban space depends on the saturation and quality of those elements. According to GYURKOVICH (1999) landscaping elements and greenery, and specifically their aesthetic and artistic values influence our emotions, what facilitates the memorization of their forms, and create the character of a place. Both the spatial forms of buildings, and the elements of landscape architecture create places, and the quality of those elements determines whether people frequent them willingly. Urban furniture keeps us in public spaces. The respondents evaluated ${ }^{3}$ the $^{2}$ condition of the equipment of public spaces in Poznan with eight elements of landscape architecture: 1) artistic elements (sculptures and monuments), 2) fountains and other water springs, 3) information signs (signpost boards, pictograms, maps), 4) lighting (lamps, lanterns), 5) litter bins, 6) seats (benches), 7) advertising posters (signboards), 8) advertising pillars, information boards and other.

The condition of the equipment of public spaces in Poznan with the elements of landscape architecture is most often evaluated as good or acceptable (see fig. 1). There is a very small representation of extreme marks. The respondents gave the highest grades to artistic elements, i.e. sculptures and monuments (3.68) and fountains (3.42), deciding by the same token, that they exert the greatest influence on the quality of public spaces. A Sculpture is a work of art, concentrating attention on itself. Its greatest strength is the form and expression, which must attract attention, catch the eye and awake interest in viewers. A good sculpture (monument) should organize space, determine place, be an attractive accent in the urban structure of public space, provoke thought.

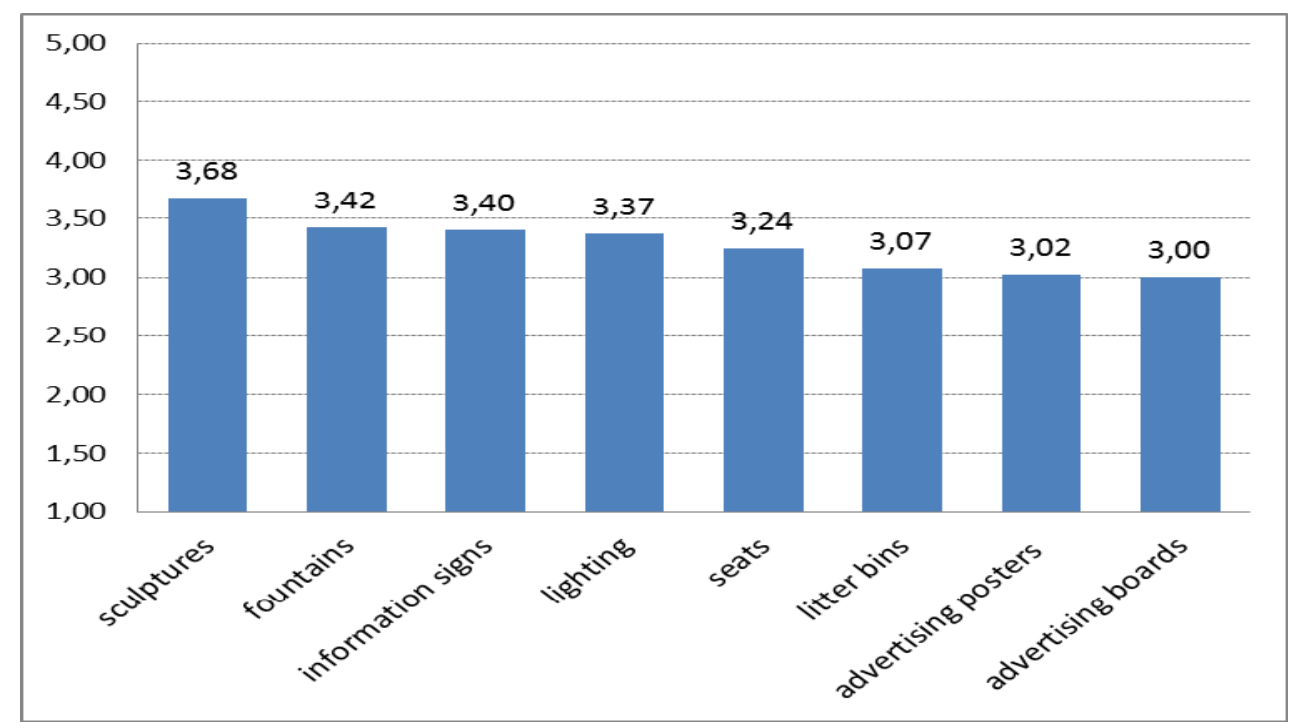

Scale of evaluation: 1 (very bad), 2 (bad), 3 (satisfactory), 4 (good), 5 (very good).

Fig. 1. The evaluation of the equipment of public spaces in Poznan with the elements of landscape architecture (weighted average). Source: own study

\footnotetext{
3 The evaluation of the condition of the equipment of public space is a weighted average. While assessing the elements of landscape architecture, the respondents could award five grades: 1 (very bad), 2 (bad), 3 (acceptable), 4 (good), 5 (very good).
} 
Slightly lower marks were appointed to signposts (3.40) and lighting elements (3.37). A conclusion can be drawn that the respondents feel safe in the urban space. Grade 3.24 for seats/benches should be interpreted as the insufficient equipment with these elements of some areas of the city, and that means there are not enough places to sit down (their poor condition is also noticeable). This fact often discourages people to stop in a given area of the city. Every second respondent sees this problem (fig. 1.). The lack of seats is noticeable in places like: parks, playgrounds, shopping streets, stations or the Old Square.

The respondents most often point out the problem of advertisements (grade 3.02) whose policy is not regulated, the overflow of information and the frequent inappropriate use of advertising pillars and information boards (grade 3.00). The problem of litter bins (grade 3.07) which are overfilled or there is an insufficient number of them is also quite transparent. Almost $40 \%$ of respondents notice this problem (see fig. 1.). It is an important matter, because it pertains to the maintenance of cleanliness in the city. Cleanliness is a significant factor influencing the quality of life of inhabitants. Dirt and waste have a negative effect on the image of a given place, they interfere with the aesthetics, lower the mood of the inhabitants - neglecting this problem by the city authorities may lead to that effect. On the other hand, aesthetic space may bring benefits not only to the city dwellers, but also contribute to the improvement of the image of the entity outside.

The shortage of equipment with some elements of landscape architecture is confirmed by the next part of the analysis of the responses given in the survey. $2 / 3$ of them emphasize the shameful but very serious problem of insufficient number of public toilets (fig. 2.). Such facilities are missing in Poznan mostly in places like: the old town, city squares, parks, tourist tracks, and recreational areas around lakes. If truth be told, there are a numerous dining, sales and culture places where one can find toilets, but these are usually available to the customers only. Every city should offer access to public toilets. These facilities do not have to look ugly, on the contrary, there are many examples around the world, demonstrating that toilets can be aesthetic and have an interesting architecture.

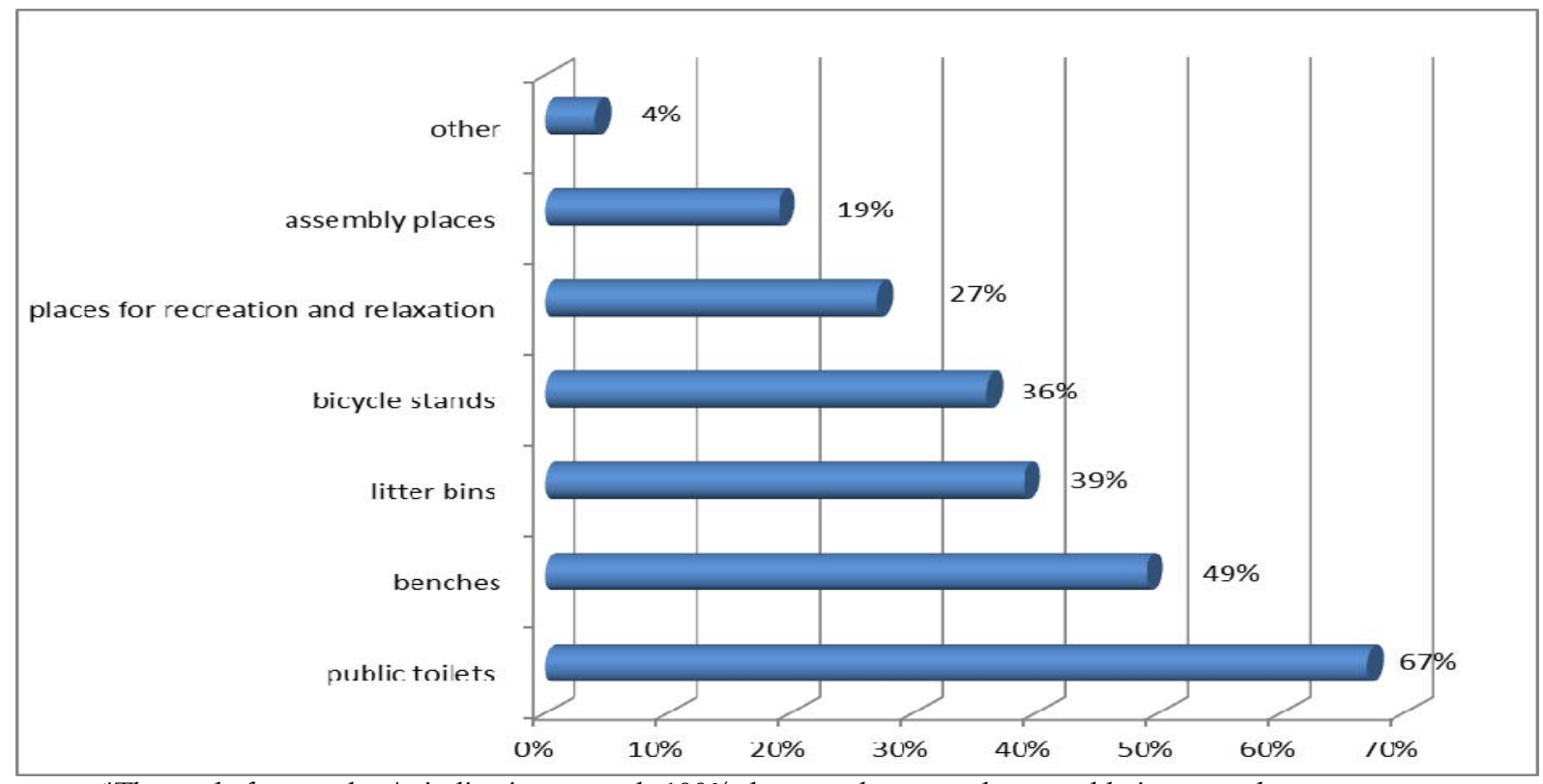

${ }^{*}$ The total of respondent's indications exceeds $100 \%$, because the respondents could give more than one answer.

Fig. 2. The shortcomings pointed out by the respondents in the public spaces of Poznan (\% respondents indicating the given option). Source: own study.

Important problems the respondents usually point out include also: insufficient number of bicycle stands (36\% of indications), insufficient amount of recreation and relaxation places $(27 \%)$ and assembly places $(19 \%)$ where people can gather in order to participate in an event (fig. 2.).

\section{The evaluation of the quality of the public space of Poznan}

In the next part of the survey the respondents evaluated how the accessibility, functionality, aesthetics, cleanliness and safety influence the quality of public spaces in Poznan. Semantic scale was used for the evaluation. The analysis of averaged results indicates unanimously a positive evaluation 
of these features. They are, however, quite diversified (fig. 3.). The highest grade (1.93) was given to the accessibility of public space, which is the most significant feature from the economic point of view. Every fourth person stated that public spaces in Poznan are easily accessible and that this fact has a positive effect on the quality of those spaces. A mere $4 \%$ of respondents believe that it is difficult to reach the public spaces of Poznan, that they are badly designed and managed, which discourages from using them.

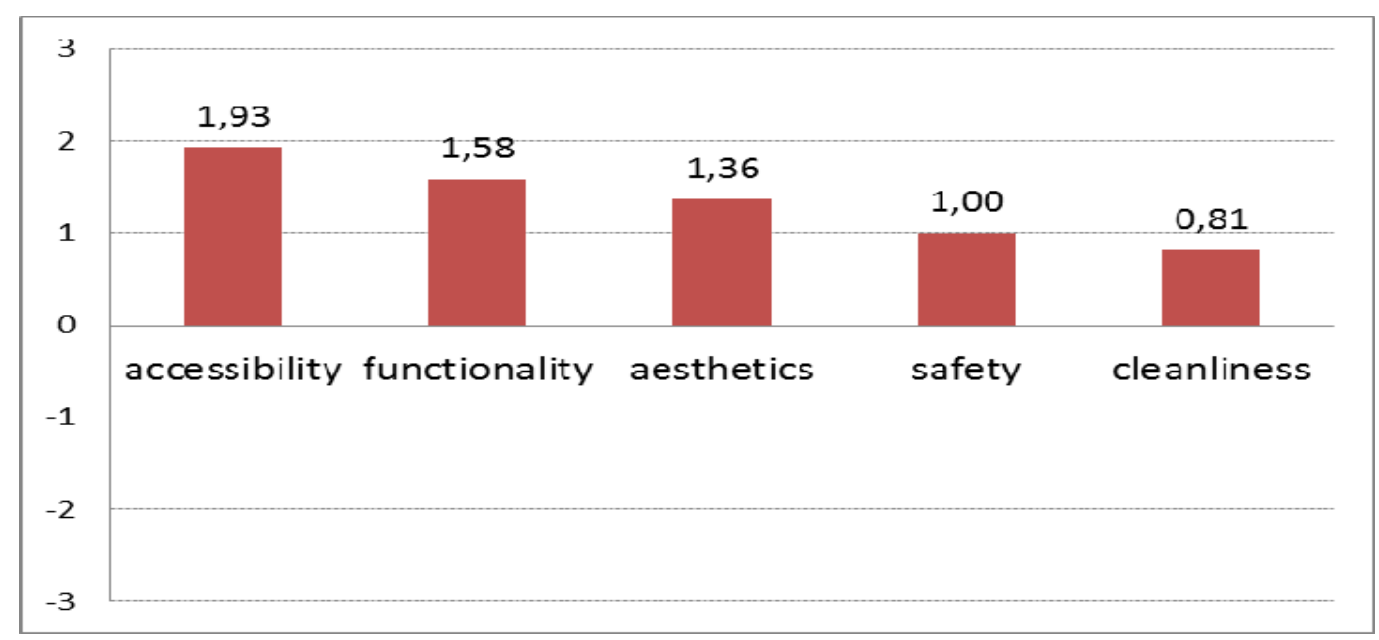

Scale of evaluation: -3 (very bad), -2 (bad), -1 (insufficient), 1 (satisfactory), 2 (good), 3 (very good)

Fig. 3. The evaluation of the characteristics affecting the quality of public spaces of Poznan (weighted average). Source: own study

Functionality is also a characteristic which receives positive evaluation of virtually all respondents, who believe that the public spaces in Poznan fulfil the functions which can satisfy the needs of the society in different aspects. Almost $60 \%$ of the users of public spaces of Poznan evaluate their functionality as good or very good, however almost $40 \%$ evaluate it as satisfactory and requiring small improvements.

One of the roles that public space should play is providing positive aesthetic impression. Attractive appearance is the feature encouraging its users, inhabitants or potential investors to visit the place. The general evaluation of the respondents asked about the aesthetics of the spaces of Poznan was positive (rate value 1.36). Only $10 \%$ of respondents surveyed were dissatisfied with the appearance of public spaces of Poznan, and exactly $3 \%$ of those point out the conditions requiring many improvements.

The quality of life is to a great extent dependent on the sense of security. If we feel safe in a space, it translates to the comfort of our life. When asked whether they felt safe while in the public spaces of Poznan the respondents evaluated this condition as sufficient (1.0). Almost $40 \%$ of them feel safe generally, although not entirely. Every fourth person does not feel safe in the generally accessible areas and believes that they require significant improvements in this respect.

Cleanliness of public spaces is very important and the quality of life depends on this factor to a high degree. This characteristic when referring to the public spaces of Poznan awarded the lowest marks of all the characteristics under evaluation (0.81). Therefore, $10 \%$ of the respondents expressed a definite need for the improvement of cleanliness.

\section{Summary}

Public space, as the name implies, indicates its public character, and is, therefore, a common good. It is meant to serve everyone. Public spaces fulfil different functions and satisfy the needs of its users in different aspects of their lives. Poznan has a number of interesting public spaces, with which the inhabitants in particular identify themselves and where they spend time with pleasure. Their spatial arrangement is an important element of the functional composition of urban structure. The most attractive 'common spaces' are located in the city centre.

The research activities conducted on the equipment and quality of public spaces of Poznan permit the formulation of the following generalizing conclusions: 
- the quality of life in the city depends on the condition of equipment of public spaces,

- the elements of landscape architecture increase the attractiveness of the public space of Poznań, making it more functional. They also fulfil the important role of increasing the aesthetics of the urban space - they make it more beautiful, creating a unique character of places. They also make places memorable and recognizable,

- the condition of equipment of public spaces with landscaping elements is evaluated as good, or satisfactory. Particularly high marks are given to the artistic elements, i.e. monuments, sculptures and fountains, as well as signposts and lighting. Sculptures in Poznań are interesting and almost $60 \%$ of respondents noticed their aesthetic value, appreciating also their uniqueness,

- the users of public spaces in Poznań noticed a problem with the insufficient quantity of seats (especially in the Old Square),

- the most problematic areas turned out to be: advertisement pillars, advertisements and signboards,

- the insufficient number of public toilets is noticeable in Poznań.

The quality of public space of the city determines its attractiveness to a great extent, including, as indicated by the reference literature (MARKOWSKI 2001), indirectly the attractiveness for investments. Considering the quality of public spaces, the attractiveness of Poznan in the opinion of the respondents is unanimous. Every second person is convinced about the high quality of these places, and about the fact that they make the image of the city more attractive on the outside, as well as about the benefits they bring to the city dwellers. Such characteristics of public spaces as: accessibility, functionality, aesthetics, safety determine their quality, and according to the respondents, Poznan is an attractive city in terms of the quality of public spaces. If truth be told, we cannot talk about the absolute attractiveness of the city, but based on the evaluations of respondents shaped by their system of values, knowledge and the image in the media, as well as the degree of satisfaction of needs, a generally positive evaluation (good) can be given to the public spaces of Poznań.

\section{References}

AleXANDER Ch., ISHIKAWA S., Silverstein M., JACOBSON M., FIKSDAHL-King I., ANGEL S., 2008, Jezzyk wzorców. Miasta, budynki, konstrukcja (Language of patterns. Towns, buildings, construction), Wydawnictwo GWP, Gdańsk.

CZEPCZYŃSKI M., 2012, Przestrzeń publiczna jako forma reprezentacji społeczności lokalnych. Między hibernacja a animacją centrów matych miast woj. pomorskiego (Public space as a form of representation of local communities. Between hibernation and animation of town centres of Pomorskie Voivodeship), (in:) K. HefFner, T. MARSZAŁ (ed.), Przestrzeń publiczna matych miast, Studia KPZK PAN, T. CXLIV, Warszawa.

DYMnICKA M., 2009, Przestrzeń publiczna a przestrzeń społeczna (Public space vs. social space), (in:) A. Golędzinowska (ed.), Wspótczesne kształtowanie przestrzeni publicznej województwa pomorskiego, Pomorskie Studia Regionalne, Gdańsk.

FILIPCZUK H., 1988, Dziecko w placówce wychowawczej (Child in educational institution), Warszawa.

GRACZYK R., STASZEWSKA S., 2012, Przestrzenie publiczne małych miast miejscem życia spotecznego (Public spaces of small towns as venues of social life), pp. 136-137 (in:) K. HEFFner, T. MARSZAE (ed.), Przestrzeń publiczna matych miast, Studia KPZK PAN, T. CXLIV, Warszawa.

GYURKOVICH J., 1999, Znaczenie form charakterystycznych dla ksztaltowania i percepcji przestrzeni (The importance of forms typical for the shaping and perception of space), Monografia 258, Kraków.

HefFner K., Marszat T. (ed.), 2012, Przestrzeń publiczna matych miast (Public space in small towns), Studia KPZK PAN, T. CXLIV, Warszawa.

Karta Przestrzeni Publicznej (The Public Space Charter) 2009, www.tup.org.pl/download/2009_0906_KartaPrzestrzeniPublicznej.pdf

KoCHANOWSKA D. , 2010, Przestrzeń publiczna - kluczowy element miasta wspótczesnego - zintegrowana czy podzielona? (Public space - a key element of a modern city - integrated or divided?), (in:) P. LORENS, J. MARTYNIK-PĘCZEK (ed.), Problemy kształtowania przestrzeni publicznych, Wydawnictwo Urbanista, Gdańsk.

KowALCZYK J., 2009, Paradygmaty zmian w przestrzeni publicznej kobiet (Paradigms of change in the public space of women), Teka Kom. Politol. i Stos. Międzynar. - OL PAN.

LITWIŃSKA E., 2012, Czy można mówić o specyfice przestrzeni publicznych małego miasta? (Can we talk about any specific characteristics of public space in small towns?), (in:) K. HEFFnER, T. MARSZAŁ (ed.), 
Przestrzeń publiczna matych miast, Studia KPZK PAN, T. CXLIV, Warszawa.

LORENS P., 2010, Główne typy i rodzaje wspótczesnych przestrzeni publicznych (Major types and kinds of modern public space), (in:) LORENS P., MARTYNIK-PĘCZEK J. (ed.), Problemy kształtowania przestrzeni publicznych, Wydawnictwo Urbanista, Gdańsk.

MAGA - JAGIELNICKA R., 2012, Standardy publicznych przestrzeni miejskich (Standards of cities public spaces), (in:) Heffner K. (ed.), MARSZAŁ T. (ed.), Przestrzeń publiczna matych miast, KPZK PAN, Warszawa.

MARKOWSKI T., 1999, Zarzadzanie rozwojem miast (Managing of urban growth), PWN, Warszawa.

MARKOWSKI T., 2001, Rozwój regionalny i przestrzeń publiczna (Regional development and public space), Komitet Przestrzennego Zagospodarowania Kraju PAN, Warszawa.

Sierecka - Nowakowska B., 2001, Dziedzictwo przyrodniczo - kulturowe jako podstawa rozwoju przestrzeni publicznej miasta na przykładzie Łodzi (The natural and cultural heritage as a basis for the development of urban public space on the example of Łódż), (in:) MARKOWSKI T. (ed.), Rozwój regionalny i przestrzeń publiczna, KPZK PAN, Warszawa.

Ustawa z dnia 27 marca 2003 r. o planowaniu i zagospodarowaniu przestrzennym, (Act of 27 March 2003 on planning and spatial development, Journal of Laws of 2003 No. 80, item 717).

WEJCHERT K., 1974, Elementy kompozycji urbanistycznej (Elements of urban composition), Wydawnictwo Arkady, Warszawa.

ZBIERSKA I., 2010, Wptyw formy przestrzeni publicznych w środowisku zamieszkania na emocjonalna więź z miejscem (The influence of the form of public spaces in the residential environment on the emotional bond with the place), Architektura. Czasopismo techniczne (Technical Transactions), Issue 6, Wyd. Politechniki Krakowskiej, Kraków. 